\title{
FROM ACTION THEORY TO THE THEORY OF THE FIRM
}

\author{
Antonio Argandoña
}




\title{
FROM ACTION THEORY TO THE THEORY OF THE FIRM
}

\author{
Antonio Argandoña ${ }^{1}$
}

\begin{abstract}
Since Coase's (1937) pioneering article, the theory of the firm, especially in its neoclassical form, has developed tremendously. The criticisms leveled against it confirm its interest and usefulness - which is not to say that it cannot be improved upon or corrected in many respects. This chapter is intended to contribute to a broadening of the theory of the firm, starting from a theory of human action that encompasses a wide range of motivations. It also suggests specific ways in which the conception of the firm can be improved.
\end{abstract}

Keywords: Action, action theory, firm, motivations, organization, theory of the firm.

\footnotetext{
${ }^{1}$ Professor of Economics, "la Caixa" Chair of Corporate Social Responsibility and Corporate Governance, IESE
} 


\section{FROM ACTION THEORY TO THE THEORY OF THE FIRM}

\section{Introduction $^{1}$}

Economics traditionally has concerned itself with the efficient use of scarce resources that are used for alternative purposes (Robbins, 1934). The prime locus of economic efficiency is the market, where subjects conduct transactions which, under certain conditions, optimize the use of resources. Coase (1937), however, finds that in this scenario there appear certain organizations, the firms, in which voluntary market exchanges are replaced by decisions made by means of authority. This is the starting point for the neoclassical institutional theories of the firm that now dominate the economics departments of universities and business schools.

It is not my intention here to explain these theories or their variants. ${ }^{2}$ Together they make an excellent, well founded, well developed whole that has contributed decisively to our understanding of the firm and the large questions surrounding it, which are, principally, why the firm exists, its boundaries and its internal organization (Holmström and Tirole, 1989). The institutional theories have been criticized on conceptual and methodological grounds (Foss, 2007; Foss and Klein, 2006, 2008, 2009) and on the grounds of their practical consequences (Donaldson, 2002; Ferraro et al., 2005; Ghoshal and Moran, 1996). Yet this does not diminish their theoretical and empirical importance. Whatever one's conception of the firm, any theory of the firm must take account of transaction costs, property rights, agency problems, information asymmetries, moral hazard, asset specificity, rent-seeking, incomplete contracts, opportunism and hold up, team production, shirking and many other aspects of institutional theory. That is why these theories are considered the mainstream.

\footnotetext{
${ }^{1}$ This study is part of the research of the "la Caixa" Chair of Corporate Social Responsibility and Corporate Governance, IESE Business School. The views expressed in this article are the sole responsibility of the author and do not necessarily reflect in any way the views of Caja de Ahorros y Pensiones de Barcelona "la Caixa" or of IESE and its faculty.

${ }^{2}$ What I here call institutional theories of the firm are a set of theories that are partly complementary and partly substitute. They originate from Coase (1937) and have developed in various branches: the transaction costs branch (Williamson, 1971, 1975, 1985), the nexus of contracts or property rights branch (Alchian and Demsetz, 1972; Grossman and Hart, 1986), the agency theory branch (Ross, 1973), and others, all of which are subdivided and interwoven. Strictly speaking, not all are theories of the firm. Agency theory, for example, does not explain the boundaries of the firm, in terms of ownership of assets. We shall not go into these distinctions here, however.
} 
There are other, alternative theories, which could be termed cybernetic institutional theories. ${ }^{3}$ They differ from the neoclassical institutional theories mainly in their conception of the economic agent as an open system (hence the term 'cybernetic') and of the rationality of human action, which, in their conception, is not complete and closed to outside influence but is open to learning. To be included in this category are evolutionary theory (Nelson and Winter, 1982), the theory of competencies or capabilities (Penrose, 1959; Richardson, 1972) and the Austrian theories (Dulbecco and Garrouste, 1999; Foss, 1994; Ioannides, 1999; Lewin and Phelan, 2000; Yu, 1999). ${ }^{4}$ Nelson and Winter pay particular attention to the strategy of the firm in its dealings with the environment, the firm's structure or institutional 'memory', and firm capabilities, thus tying in with a second group of theories which conceive of the firm as a nexus of capabilities that are to a greater or lesser extent shared by the firm's members, effectively making the firm a means of coordinating the knowledge possessed by its members. The Austrian theories, in contrast, emphasize, among other aspects, the action of the entrepreneur, the subjective nature of action and the fact that action takes place under conditions of ignorance and uncertainty $\dot{a}$ la Knight (1921).

Economics starts always from a theory of human action (although it does not always make that theory explicit). Mainstream theories about the firm adopt a limited view of human action, as they concern themselves with what distinguishes exchange-oriented action from the action that takes place inside firms, which is characterized by authority. ${ }^{5}$ The first question Coase (1937) asks is why are there 'islands of conscious power in this ocean of unconscious cooperation, like lumps of butter coagulating in a pail of buttermilk?' (Coase, 1937, p. 388, citing D. H. Robertson). In theories of the firm, therefore, the market is the model; and the human action these theories are concerned with is the action that manifests itself in exchange, be it in the market or in the firm. This is particularly important when discussing the subjects' motivations. In the theories we are considering, the motivation that counts most - and in some cases the only motivation that counts - is what is usually known as extrinsic motivation, i.e. what rational subjects pursue when they exchange goods in the market; other types of motivation are irrelevant to them.

Limited, as they are, to exchange, these theories are not intended to explain human organizations in general, only for-profit business firms. Other organizations will require a different explanation, which may coincide with the theory of the firm insofar as it describes how these other organizations seek to achieve economic efficiency, just like companies (Posner, 2010).

On the other hand, if what differentiates a firm from the market (at least at first sight) is the existence of relations of authority or hierarchy, the theories of the firm will conceive of decision making in terms of a principal who gives orders and one or more agents who obey. What they will try to explain is how the agents can be induced to cooperate in achieving the goals set by the principal, for example what contracts can be written, what incentives can be offered, how the agents can be monitored and controlled, and other similar matters. All this revolves around the contract as the central institution, both in the market and in the firm (although the contracts will be structured differently in each case). What matters, therefore, is

\footnotetext{
${ }^{3}$ The term is from Martínez-Echevarría (2000); cf. also Martínez-Echevarría (2005).

${ }^{4}$ Despite frequent claims that there is no Austrian theory of the firm (Langlois, 1991; O'Driscoll and Rizzo, 1985), 'many of the analytical components that are necessary to tell a coherent story about why there should be firms in a market economy were present in Austrian theorizing long before they became standard fare in neoclassical economics' (Foss, 1994, p. 32).

${ }^{5}$ If the firm is simply a nexus of contracts, as Fama (1980) and Cheung (1983) maintain, there is no place for authority in the firm.
} 
the formal organization, the assumption being that the informal organization is immaterial (Pérez López, 1993, p. 16). This also implies that theories about the internal organizational structure of the firm will be left to other disciplines. ${ }^{6}$

The purpose of this chapter is not to pick holes in mainstream theories of the firm, but rather to show how a broader action theory may help to overcome some of their limitations. In the following section we shall briefly explain the basics of that broader action theory and its implications for human organizations. After that, we shall make some suggestions about what the broader action theory might entail for the theory of the firm - not a proposal, just some general indications of where the conventional theories could be improved - ending with the conclusions.

\section{An Action Theory}

Our starting point will be a fairly general theory of rational action. ${ }^{7}$ Let us assume that the subjects act in order to move from a less satisfactory situation to a more satisfactory one (here we shall deal exclusively with actions that involve interaction between a personal subject, the 'active agent,' and another subject, the 'reactive agent'). The effect or outcome the active agent hopes to achieve may be extrinsic (the satisfaction she derives from the reactive agent's response) or intrinsic (an internal effect that does not come from the reactive agent, for example, what the active agent learns, or the satisfaction she derives from the action itself) or external (an effect on the reactive agent, but only insofar as this effect does not have extrinsic or intrinsic effects on the active agent) (Pérez López, 1991).

This gives rise, in turn, to three possible motivations for action, depending on the outcome the active agent hopes to achieve: extrinsic (due to the effect the reactive agent's response has on the active agent), intrinsic (due to what the active agent does and the effect it has on her) and transcendent (due to the effect the active agent expects the interaction to have on the reactive agent). ${ }^{8}$ All three motivations are relevant and may occur simultaneously; there is no reason why one should predominate over the others. Although, in economic activity, extrinsic motivation is the first to appear, we cannot ignore the other two, not even in exchanges that take place in the market or actions that take place inside the firm.

The active agent could be, for example, an entrepreneur who wants to seize a business opportunity in order to obtain an economic profit (extrinsic motive), win social recognition (extrinsic), have the personal satisfaction of achieving what he set out to do (intrinsic), help other people (transcendent), have the personal satisfaction of helping others (intrinsic) or receive recognition for helping others (extrinsic). The active agent could also be a manager (agent), who serves an owner (principal) and manages an employee out of motives that may be extrinsic (to earn a salary, including the possibility of appropriating the rents generated by the business, within the agency relationship with the principal), intrinsic (learning, satisfaction) or

\footnotetext{
${ }^{6}$ For example, behavioral (March and Simon, 1958; Cyert and March, 1963), knowledge-based organizations (Kogut and Zander, 1992; Nonaka and Takeuchi, 1995), evolutionary (Nelson and Winter, 1982; Henderson and Clark, 1990), resource-based (Penrose, 1959; Wernerfelt, 1984) and competencies or capabilities (Richardson, 1972; Langlois, 1992). Not all these theories are theories of the firm, properly speaking, insofar as they do not try to explain why firms exist or the boundaries of firms.

${ }^{7}$ In this section I draw heavily on the ideas of Pérez López (1991, 1993, 1998); cf. also Argandoña (2007, 2008a, b, c).

${ }^{8}$ They are called transcendent because their effects go beyond, 'transcend' the active agent.
} 
transcendent (customer service, professional and human development of the employee, fulfillment of a duty to the principal). As the action theory is general in scope, the employee, too, can be seen as an active agent, whose motives may be extrinsic (pay, promotion, recognition), intrinsic (learning, enjoyment of the job) or transcendent (serving customers, satisfying his manager, helping his co-workers).

Actions have consequences, the extrinsic outcomes intended by the active agent, but also other effects on both the active and the reactive agent. When a person acts, she acquires operational learning (knowledge, capabilities and skills that make her better at what she does and that make what she does more enjoyable - or less so, if it becomes repetitive). And when a person seeks external results, he acquires evaluative learning (ability to value people and actions, insofar as they affect people, and as a result, motivation to perform tasks and ability to solve other people's problems). In either case, what the person learns changes her preferences and rules of action, which means that she may decide differently in the future.

Every action produces the abovementioned results, which are always present to some extent, whether deliberately sought or not. We therefore have three criteria for evaluating the active agent's action: the satisfaction obtained as a result of achieving the expected or desired extrinsic outcome (which we shall call effectiveness); the satisfaction obtained as a result of achieving the internal outcome (efficiency), which will make it easier or more difficult for the active agent to achieve the same extrinsic outcomes again in the future; and the changes that take place in the reactive agent as a result of the interaction, which will make it easier or more difficult to interact with the same reactive agent again in the future (consistency) (Pérez López, 1991, pp. 36-38). ${ }^{9}$

Effectiveness, efficiency and consistency can act in different directions. An action plan may be effective (the employee does what the manager orders him to do), but inefficient (the manager becomes increasingly reluctant to give orders) or inconsistent (implementing the action plan makes it more difficult, or even impossible, to implement the same action plan again in the future with this reactive agent). ${ }^{10}$ An inconsistent plan results in negative learning on the part of the active agent, insofar as it makes the agent, probably without realizing it, less able to see what is really important in the interaction until it is too late (Pérez López, 1991, p. 55). ${ }^{11}$

Evaluating an action, therefore, is not a trivial task. There are three reasons why not:

1) One has to take into account not just one criterion (effectiveness), as is usually the case in economics, but three, which may act in opposite directions - and there is no law to tell us how and when they will differ.

2) The relationships between the three criteria are not obvious. There is a certain trade-off between effectiveness and efficiency: an employee with high intrinsic motivation will perform better and probably need less extrinsic motivation; similarly, a greater financial reward is likely to be sufficient to induce the

\footnotetext{
${ }^{9}$ Note that we are using the terms effectiveness and efficiency in a different sense from the one in which they are generally used in economics (Grandori, 2001).

${ }^{10}$ An extreme example would be a decision to cut off a branch of a tree in order to reach the fruit on it: the action is effective but totally inconsistent. Another example would be a manager who abuses an employee's trust and so makes it more difficult to get the employee to collaborate in the future.

${ }^{11}$ That such learning can lead to a reconstruction of preferences during the actual decision-making process is well known (Kahneman and Tversky, 2000), but the possibility of negative learning is not usually taken into account in economics.
}

4 - IESE Business School-University of Navarra 
employee to accept a more unpleasant job. But that will not always be the case: given an assignment she does not like, the employee may react by accepting the assignment because it is what the firm requires of her, or she may protest because she feels mistreated, or she may demand a pay raise, or she may adopt an attitude of refusal - and this reaction may change over time.

3) The relative importance of the three outcomes is not obvious. The active agent will naturally do his best, perhaps spontaneously, to take the extrinsic effects (effectiveness) of his action into account, and possibly also the intrinsic effects (efficiency); but he will not consider the external effects (consistency) except with a conscious, positive effort. And the changes in the effectiveness, efficiency and consistency of his action will change the agent's decision rule, 'the set of operations (...) by which an active agent chooses an action’ (Pérez López, 1991, p. 28).

The rational action theory outlined here may serve as a basis for a general theory of organizations. ${ }^{12}$ An organization is 'a group of people who coordinate their actions to achieve objectives in which they all have an interest, albeit for different reasons' (Pérez López, 1993, p. 13), objectives which they would not be able to achieve, or would find it more difficult to achieve, if they did not work together and coordinate their actions (Rosanas, 2008, p. 447). ${ }^{13}$ Organizations therefore exist to achieve certain common goals in a way that is compatible with the 'different reasons' of their members, at least as far as the available resources allow (Finnis, 1998).

Whatever the aims of an organization may be, managers must achieve them, and to do so they must secure the cooperation of the members of the organization, that is, of the people (owners, employees, suppliers, customers and other stakeholders) who possess the human and material resources the company needs. ${ }^{14}$ The neoclassical institutional theories assume that this is achieved through a set of contracts that provide the necessary incentives for the agents to act in the principal's interest. The action theory, however, suggests that the problem is somewhat more complex than this. If the subjects can act out of three types of motivation, managers must monitor three state variables:

1) Effectiveness, which represents the difference between the economic results obtained by providing a service to consumers and the resources employed, roughly equivalent to profit - which is why this variable could also be called profitability.

2) The organization must also be attractive to its members, which it will be if it develops skills in its members that enhance their satisfaction or reduce the cost for them of doing what the organization requires of them, that is, if it develops the distinctive abilities that enable it to solve problems more effectively, or

\footnotetext{
${ }^{12}$ The organization theory outlined here is perhaps overdependent on the theory of individual action from which it takes its departure. To keep our explanation simple we have not considered elements that go beyond the mere aggregation of personal actions, such as a firm's culture or history (which gives rise to phenomena such as path-dependence).

${ }^{13}$ March and Simon (1958) also stress the coordination of actions and the variety of motivations when they define the organization as 'a system of coordinated action among individuals who differ in the dimensions of interests, preferences and knowledge.' The 'diversity of knowledge' component, which is not explicitly mentioned in Pérez López (1993), occupies a very important place in the theory of the firm, especially in the Austrian and capabilities schools (Foss and Klein, 2009).

${ }^{14}$ This means that subordinates' decisions have an impact on the effectiveness, efficiency and consistency of the decisions of their superiors and, therefore, of the organization as a whole.
} 
solve more complex problems, because its members have a better knowledge of the needs to be met and are more capable of meeting them.

3) Lastly, the organization must also achieve consistency in its actions, which it will do when its members identify with it and start to trust one another.

The significance of these state variables in the organization is similar to the significance they have in the subjects' behavior, as the subjects learn through their actions; and what they learn changes their future behavior and therefore also their relations with the other agents, that is, with the organization. The immediate consequences of those actions therefore will not coincide with their long-term results and an organization must strive not only to achieve immediate results but, above all, to build the capacity to continue to obtain results in the future (consistency) and ensure that the results are the best possible.

These three state variables are therefore necessary for the survival and development of any organization, especially firms. Profitability is a necessary condition for a firm's long-term survival because it allows a firm to satisfy its members' extrinsic motivations. The firm must offer its employees a salary that is greater than their opportunity cost (the salary they could earn in comparable alternative employment); and it must offer its owners remuneration equal to or greater than what they could obtain in the capital market for the same level of risk. For this to be possible, the combined cost of the contributions of all the firm's suppliers of resources must not be greater than the revenue the firm obtains from the sale of its products or services. ${ }^{15}$

However, profitability is not the key condition for the existence of the firm nor the measure of its success as an institution. 'The necessary and sufficient condition for an organization to really exist is that there be a group of people who are motivated to belong to that organization, with all that such belonging implies for them. The organization's objectives must be oriented to conserving and increasing those motivations, as otherwise the organization would disintegrate' (Pérez López, 1981, p. 5).

In order to achieve this, the organization must fulfill at least some of the requirements, in terms of attractiveness, that motivate people to contribute. First, the job that each person does in the firm (as owner, manager or employee) must not be unpleasant for him, or at least not so unpleasant as to make the person put in less effort than is needed for production. Second, it must allow job-related operational learning that will make the person's future actions more effective (Pérez López, 1991, p. 90), bearing in mind the possibility of negative learning, for example if the work is boring and repetitive. Up to a point, therefore, there is a trade-off between profitability and attractiveness, insofar as a firm must pay more for unpleasant work than for pleasant work. ${ }^{16}$

Lastly, the organization must also take into account the consequences for consistency, which in the long run could modify the outcomes achieved. Profit maximization does not guarantee a stable, long-term solution because the decisions a manager makes today will influence what

\footnotetext{
${ }^{15}$ The effectiveness we are talking about here will coincide with return on capital if all resources other than capital receive a remuneration that is fixed in advance in a contract (extrinsic motivation), but only if all the other motivations of the owners of those other resources remain unchanged - which, as a rule, will not be the case.

${ }^{16}$ Only up to a point, however, as the trade-off has limits. If the employee has material needs, the firm will have to pay him a wage even if the work is very pleasant and satisfying. And if the work is very unpleasant, simply paying a higher wage will soon have diminishing returns.
}

6 - IESE Business School-University of Navarra 
people learn and thus how attractive they find the idea of collaborating with the organization again in the future; above all, the manager's decisions will influence people's willingness to collaborate and the manager's own ability to get them to collaborate. These are three interrelated aspects of reality; they are not independent, they cannot be reduced to one another, and they cannot be processed using a single, common unit of measure (Pérez López, 1990, p. 180). ${ }^{17}$

Accordingly, while every decision within the organization must necessarily respect certain minimum levels of profitability and attractiveness, this does not guarantee the achievement of a sufficient degree of consistency in the long run. For that, everybody must act with at least a minimum of transcendent motivation, taking the needs of others into account - not because of the consequences this may have for the utility of the active agent, but because of the consequences it will have for the other. This means that the agents must be capable of evaluating the consequences of their actions not only for themselves (in terms of effectiveness and efficiency) but also for others (in terms of consistency). This is an imperative not only for those in positions of command, but also for those that obey.

In summary, every human action has three types of effect, extrinsic, intrinsic and external, which, in turn, sustain three types of motivation, extrinsic, intrinsic and transcendent, and establish three state variables, profitability, attractiveness and consistency, that every organization must satisfy in the long run. We have also pointed out that the three types of motivation are independent; each relates to the other two, but none dominates. All three are necessary and a complete lack of any one of them may result in the failure of the organization. The three state variables therefore cannot be summed up in a single variable.

\section{From the Action Theory to the Theory of the Firm}

As we explained, the purpose of this chapter is to outline an action theory that is broader than the neoclassical and Austrian ones and to show how such a theory could in some cases broaden, in others correct or qualify but not replace the institutional theories of the firm. What follows is a set of conjectures, which, to the extent that they are well founded, suggest a wideranging program of research.

\section{Action theory and motivations}

Our starting point is a unified action theory. The starting hypothesis of the neoclassical theories of the firm is 'in the beginning was the market' (Williamson, 1985, p. 87). Alternatively we propose a general human action theory ('in the beginning were the agents, acting in relation to one another') that explains both market exchanges and relations of authority in the firm as

\footnotetext{
${ }^{17}$ Maximizing profits in the short term, as if there were no learning and the other variables were constant, will not work because evaluative learning will obviously occur, in which case the conditions for maximum effectiveness will no longer be met. And maximizing profits in the long term, anticipating all the learning that will take place, is equally impossible because although we know that the agents will learn, we do not know what or when they will learn. In the language of neoclassical economics, the three dimensions (profitability, attractiveness and consistency) cannot be integrated, on the personal level, in a single preference or utility function or, on the organizational level, in a single objective function (such as maximizing the value of the shares).
} 
particular cases of the agents' action in relation to one another. ${ }^{18}$ This action theory would start with the subject acting on her own (the theory of the consumer, for example, but including operational and evaluative learning); it would continue with occasional relations between agents, before moving on to lasting relationships that demand some kind of coordination (organization theory), and it would end with a particular case, the theory of the firm.

This theory includes different types of motivation, namely extrinsic, intrinsic and transcendent. This is not new: neoclassical theory also accepts a diversity of preferences, both selfish and altruistic, in the same utility function; intrinsic motivation has been elaborated upon in the social psychology, sociology and economics literature; ${ }^{19}$ and various theories of altruistic, prosocial or other-related behaviors have been developed..$^{20}$

However, the action theory presented here adds at least three clarifications to that diversity of motivations: 1) there are no precise relationships between the different motivations and no tradeoffs that can be exploited to reduce one to another: they cannot be treated as part of the same utility function; 2) organizations must satisfy at least extrinsic and intrinsic motivation in order to be viable even in the short term, and 3) there is a certain order of motivations: for example, extrinsic and intrinsic motivations tend to receive more attention in the short run, but, for an organization to survive in the long run, (all) the agents must be capable of acting with at least a minimum of transcendent motivation. To put it another way, it is not enough to add intrinsic and transcendent motives 'from outside;' the theory must explain how all three are coordinated.

A broader theory of motivation would also clarify or broaden some aspects of the theory of the firm. The concepts of transaction costs, rent-seeking and opportunism, among others, may emerge more clearly if the existence of different motivations in the agents is taken into account, as well as the state variables that must be considered in the firm as conditions of longrun stable equilibrium of the system.

The agency conflict between the principal (the owner) and the agent (the hired manager), for example, would take on new dimensions. As presented by Jensen and Meckling (1976), if the agent acts out of extrinsic motivation, seeking only his own economic benefit, conflict is inevitable (assuming the other conditions, especially information asymmetry, are given). And yet, as we have seen, other motives come into play and the relationships between them are not elementary. If the agent acts out of intrinsic motives and those motives are aligned with the interests of the principal, there will be no agency conflict. But agents learn, so those motives may weaken (for example, the work may start to seem routine). ${ }^{21}$ And if the agent acts out of transcendent motives (in the interests

\footnotetext{
${ }^{18}$ What happens outside the market and outside the firm may shed light on the actions we are concerned with here. Altruism and prosocial behavior, for example, cannot be taken as exceptions to 'rational' individualistic behavior. They are simply the behavior of an agent who acts out of transcendent motives (without excluding the possibility that he also acts out of other motivations).

${ }^{19}$ The distinction between extrinsic motives (a satisfaction provided by the environment) and intrinsic motives (a satisfaction internal to the agent) has long been a part of social psychology (Deci, 1975), sociology and economics (Bolton and Ockenfels, 2000; Fehr and Schmidt, 1999; Frey, 1999; Osterloh and Frey, 1997). We could also include here 'acting appropriately to the situation' (March, 1994).

${ }^{20}$ See, for example, Frey (2003), Frey and Meier (2002), Schelling (1978), Stark (1995).

21 This dynamic dimension has occasionally been dealt with in game theory, but usually under very simple assumptions. Game theory would likely gain from of a closer connection with the action theory - though probably at the expense of formal elegance.
}

8 - IESE Business School-University of Navarra 
of the principal and the firm, but not necessarily of other employees, suppliers and customers), there will be no conflict. Agency conflict is therefore a particular - probably very widespread but nonetheless particular - case of a range of possible behaviors.

This is not to say that transcendent motives are a substitute for the monitoring and control procedures put in place by the principal, or for incentives designed to align the interests of the two parties: transcendent motives cannot be created at will (they belong to the sphere of the virtues: Pérez López, 1991) and any attempts to do so may be interpreted by the agent as attempts to manipulate her motivations. In any case, the action theory presented above would allow us to address issues such as why agency conflicts occur, why they do not always occur, why they change over time (because of the nature of evaluative learning), ${ }^{22}$ what conditions must be met (in the principal and in the agent, and in the relations between them and in the organization), for such conflicts to occur or not to occur, and what are the most likely consequences of the incentive systems and monitoring methods used to combat them.

In the conventional theory the interaction between the active and the reactive agent is intended to achieve the goals set by the active agent; the employees are seen mainly as a constraint and they have to be offered compensation not to impede the desired outcome (Rosanas, 2001). A general action theory should be two-directional in order to explain, within a common framework, both the behavior of the person who gives the orders and that of the person who obeys. ${ }^{23}$ The motivations of one and the other will be the same, possibly combined in different proportions; the other components of their behavior (knowledge, capabilities, attitudes, values, etc.) will probably also be different.

This may shed some light on other issues related to the theory of the firm, such as those regarding employee participation in decision making or regarding decentralization. For instance, if an employee acts out of intrinsic motivation, she must find a meaning in the action she performs (solving a coordination problem requires understanding the action of the other: Yu, 1999). ${ }^{24}$ Similarly, if a manager acts out of transcendent motivation, he needs to be able to put himself in the other person's position in order to understand what the other person needs and how those needs can be satisfied, so as to be able to persuade him to collaborate (Pérez López, 1991). ${ }^{25}$

\footnotetext{
${ }^{22}$ So far our analysis of learning has been confined to persons, but it can be extended to the organization. Insofar as we can talk about the firm as an entity that learns, other changes will take place: the nature and amount of transaction costs and the borders of the firm, for example, will vary over time.

${ }^{23}$ This does not mean that the theory of the firm must be based on the existence of multiple principals and multiple agents, because the identity of the person who exercises power is relevant (Khalil, 1998). But the one who gives orders must not forget the variety of motivations of the one who obeys, the likelihood that those motivations will change over time and, therefore, the impact such changes will eventually have on the profitability, attractiveness and consistency of the organization.

${ }^{24}$ Another approach to coordination problems emphasizes routines, rules, procedures, recipes or conventions in the firm (Nelson and Winter, 1982; Kogut and Zander, 1996).

${ }^{25}$ Rosanas (2001) points to another aspect of this coordination of actions: the two agents have a limited and incomplete knowledge of what is best for them and it is the manager's job to 'guess' what the employee needs, so as not to create even more serious imbalances.
} 


\section{The firm as a community of persons}

In neoclassical institutional theory a firm is a collection of (physical or human) resources or assets (or of property rights on such resources or assets), which work together to efficiently produce goods and services for sale in the market; or a nexus of contracts, or routines. The fact that there are three types of motivation suggests that the emphasis should be on the people who own those resources: the firm would be better understood as a community of persons. This is not about adding a 'humanistic' touch to the theory, but of acknowledging at least three facts: 1) resources have no value without knowledge: "without the "knowledge" of how to profitably use a resource, it is not a resource, it has no value' (Lewin and Phelan, 2000, p. 71); 2) knowledge is inevitably personal, unlike information, which has an objective existence (Fransman, 1994), and 3) motivations cannot always be linked to ownership of resources, whether physical or human.

If the employees' motivations should be taken into account, a certain identification of their motivations with the firm's goals is needed. ${ }^{26}$ As we already explained, the employees' participation in the firm is justified by the need to achieve extrinsic, intrinsic and external outcomes, which may satisfy the employees' needs. Extrinsic outcomes belong to the category of incentives, as defined by neoclassical economics, but they cannot explain 'how employees are induced to work more than minimally, and perhaps even with initiative and enthusiasm' (Simon, 1991, p. 26): "this internalization requires (...) a reference to the plane of transcendent motives, as that is the plane on which there operates the "invisible hand" that makes what the organization wants (to satisfy human needs) coincide with what a person must want in order to develop as a person (to help satisfy the needs of other people, acting out of transcendent motives)' (Pérez López, 1993, p. 103).

This also implies that the firm must take the motivations of its employees into account in order to at least minimally satisfy their extrinsic and intrinsic motivations and foster their transcendent motivations. In other words, the firm must create a climate of trust in which each agent can be confident that the others will not act opportunistically, seeking their own benefit at the cost of harming each other. If everyone in the firm acts only out of extrinsic motives, trust is pointless, as no one will want to act in a way that might benefit another (Pérez López, 1993, pp. 156-157). Opportunism is not only a problem of economic incentives or of controls, rewards and punishments.

\section{The entrepreneur and the firm}

In neoclassical theory the profit opportunities are available and known, so there is no need for an entrepreneur to discover and judge them. ${ }^{27}$ The Austrian theories, in contrast, highlight the figure of the entrepreneur and try to incorporate it in the theory of the firm (Casson, 2000; Langlois and Robertson, 1995).

\footnotetext{
${ }^{26}$ The identification is both cognitive ('members are surrounded by information, conceptions and frames of reference quite different from those of other people outside the organization or in a different organization:' Simon, 1996, p. 44) and motivational (which entails "'he attachment to group goals and a willingness to work for them even at some sacrifice of personal goals:' Simon, 1996, pp. 43-44).

${ }^{27}$ There is no generally accepted definition of what an entrepreneur is, or what an entrepreneur does. Foss and Klein (2005, 2008) mention various alternative conceptions of entrepreneurial activity, notably, for the purpose of our analysis, those that define it as innovation (Schumpeter, 1934), discovery of opportunities (Kirzner, 1973) and judgment under uncertainty (Knight, 1921).
}

10 - IESE Business School-University of Navarra 
What does the theory of the entrepreneur add to the action theory? In principle, an entrepreneur will act out of any of the three motivations we have mentioned. Depending on the circumstances, there will be a predominance of one type or the other, be it extrinsic (making a profit) (Ioannides, 2003; Kirzner, 1973), intrinsic (doing something the entrepreneur enjoys, learning, giving expression to her creative ability) or transcendent (meeting the needs of potential customers and of other members of the company), or a combination of all three, which also may change over time (what started as an act of self-affirmation, for example, may later become primarily a pursuit of profit or primarily a commitment to serve). This does not, however, change the role of the entrepreneur; if anything, it accentuates the entrepreneur's intent to put into practice what only she knows how to do, that is, discover and judge opportunities.

The prevailing theories, especially the Austrian theory, pay special attention to the cognitive dimension of the entrepreneur, that is, the dimension that makes the entrepreneur capable of recognizing and identifying opportunities (for profit, for self-realization, for learning, or for service, depending on motivations). This brings to the fore the problem of the coordination of knowledge in the firm (Dulbecco and Garrouste, 2000; Langlois and Foss, 2009; Loasby, 2009) not in the neoclassical theories, ${ }^{28}$ but certainly in the Austrian theories and others related to them, such as the theories of capabilities.

In none of these theories, however, is there a problem of coordination of motivations, as the anthropologies underlying them assume that the agent's response to knowledge is immediate: no sooner does the agent become aware of what motivates him than he acts on it (Argandoña, 2005). If he fails to do so, it may be due to ignorance or to the motivation being insufficient (the costs of action are greater than the extrinsic rewards for the agent), which will have to be corrected by providing stronger incentives (extrinsic motivation). In fact, the neoclassical theories are more properly theories of alignment of incentives (through contracts, hierarchies or reputation) than theories of coordination of actions.

The introduction of intrinsic motives brings this assumption into question. In effect, the simultaneous operation of intrinsic and extrinsic motivations may lead to at least partial crowding out of intrinsic motivations (Frey, 1997; Bénabou and Tirole, 2003). ${ }^{29}$ The existence of transcendent motivations further complicates the analysis, as transcendent motivation may inhibit the other two types, for example in situations where the agent acts without expecting either extrinsic (no monetary reward) or intrinsic (no personal satisfaction) effects, simply for the good of others.

This means that, besides the problem of coordination of knowledge, there may also be a problem of coordination of motivation, which concerns not only knowledge but also the will: ${ }^{30}$

\footnotetext{
${ }^{28}$ The neoclassical theories usually start from very restrictive assumptions about the agents' cognitive capabilities. This is the basis of Simon's (1955) criticism of unbounded rationality. The fact that in the neoclassical theories all the agents have the same model of the environment and that this model is correct obviates the need to coordinate their knowledge; the problem is thus reduced to designing and implementing the right incentives (Cremer, 1990). Note that the problem of knowledge in the Austrian theories is not of the same nature as the problem of bounded rationality. Under bounded rationality the difficulty lies in processing a large volume of existing information, whereas in the Austrian theories the problem lies principally in discovering what knowledge is relevant.

${ }^{29}$ As Frey (2010) points out, it is not enough just to add a supposed intrinsic motivation from outside, because intrinsic motivation interacts with extrinsic motivation and changes the agents' decision rules.

${ }^{30}$ And not only the will, as motivations are based on knowledge (Pérez López, 1991): 'what a person wants and likes influences what he sees; what he sees influences what he wants and likes' (March and Simon, 1958, p. 158).
} 
the problem of how to get the people who work together in the firm, using their resources (physical capital, human capital and technology) and moved by different motivations, to act in a coordinated way to achieve an outcome in which they all have an interest, albeit for different reasons (Pérez López, 1993).

\section{A broad theory of organizations}

One of the advantages of founding the theory of the firm in a broad action theory would be to have room in it for different types of organizations, including associations, non-profit entities, cooperatives, foundations and others of a similar nature. ${ }^{31}$ What would differentiate the theory of the firm would probably be the greater relative importance of extrinsic motivation - in the firm's object (the sale of a good or service in the market for good consideration), in the involvement of the firm's members (the owners seek mainly profit and the employees, a salary) and in market conditions (for example, competition, which demands that firms be highly effective). This does not exclude the other motivations, however, either in the firm's object (which must be to serve its customers) or in relations with its members (who require satisfaction, as well as operational and evaluative learning). ${ }^{32}$

In non-business organizations the importance of some of these factors will be different, but the three state variables will still be relevant. A non-profit, for example, must pay a salary to its employees, provide work that is attractive to its volunteers, satisfy the motivations of its donors and providers of funds, and make a profit on its operations, which in this case will not be defined by the difference between sales revenue and the cost of goods sold, but will include other revenue (donations, for example) and other costs (although the opportunity cost of its volunteers will not be the market wage they could earn elsewhere, as they have renounced that option). In any case, just like a business firm, it must be capable of creating a 'fund of incentives' to satisfy its employees' extrinsic motivations.

And finally, our action theory could be a good foundation for the role of ethics in the theory of the firm. For years the relationship between economics and ethics has been governed by the principle of separation, which treats the two as absolutely disconnected realities. Under these conditions ethics can only ever be a more or less arbitrary constraint that limits the economic efficiency of decisions in the firm.

If agents act out of a variety of motivations, however, including transcendent motivation, then they must consider the effects their actions have on others: customers, owners, managers, employees, suppliers and society at large. And this not for exogenous reasons, but as part of the state variables that must be considered when making decisions. This means that there is a place for ethics in the theory of the firm (Argandoña, 2008a, c).

\footnotetext{
${ }^{31}$ And unions, political parties, churches, and the organizations studied in Posner (2010), oriented toward national security, and the judiciary.

32 Consistency or 'organizational unity depends on two circumstances, both of which must be given and both of which are therefore necessary conditions for the organization to exist: 1) The organization must measure the effectiveness of actions according to how well they satisfy people's real needs (...) [and] 2) People must be capable of acting out of transcendent motives' (Pérez López, 1993, p. 109).
} 


\section{Conclusions}

It is now generally accepted that Coase (1937) is the origin of modern theories of the firm. Based on that article, various theories have been developed that have contributed to the development of our knowledge about why the institutions we call firms exist, what their boundaries are and how they are organized internally. Naturally enough, there are criticisms of these theories, and alternative views, largely replicating what happens in other branches of economics. And many of these criticism reach back to the basic assumptions on which these theories are built.

This chapter is not intended to be yet another critique of what we have called the neoclassical institutional theories. Its goal is more modest, though perhaps still overambitious. We have taken a step back to reconsider a theory of human action that enriches the range of motivations of action; a theory that, above all, establishes some simple laws about the relations between motivations and declares certain state variables that human organizations must observe in order to achieve not just short-term results but, above all, their conditions of dynamic equilibrium in the long run. As a result, many human actions in the market and in the firm, as studied by conventional economics, become particular cases of this more general theory.

In this chapter we have outlined this broader action theory and have suggested some points where this approach may help to understand what the institutional theories of the firm contribute, broaden their point of view and correct some of their shortcomings. This may serve to improve our knowledge of the firm by linking it to other aspects of human and organizational action. The cost, however, seems high, in that the chances of formally establishing a more general theory seem slight. That is nothing new, though. It is the age-old conflict between rigor and relevance, familiar from academic debates in business schools. 


\section{References}

Alchian, A. and H. Demsetz (1972), "Production, information cost, and economic organization," American Economic Review, 62, pp. 777-795.

Argandoña, A. (2005), "La teoría de la acción y la teoría económica," in R. Rubio de Urquía, E. M. Ureña and F. Muñoz Pérez (eds.), "Estudios de Teoría Económica y Antropología," (Madrid: Unión Editorial), pp. 615-646.

Argandoña, A. (2007), "Economics, ethics and anthropology," in M. L. Djelic and R. Vranceanu (eds.), "Moral Foundations of Management Knowledge," (Cheltenham, UK: Edward Elgar), pp. 67-84.

Argandoña, A. (2008a) "Integrating ethics into action theory and organizational theory," Journal of Business Ethics, 78, pp. 435-446.

Argandoña, A. (2008b), "Anthropological and ethical foundations of organization theory," in S. Gregg and J. R. Stoner Jr. (eds.), "Rethinking Business Management. Examining the Foundations of Business Education,” (Princeton, NJ: The Witherspoon Institute), pp. 38-49.

Argandoña, A. (2008c), "Consistency in decision making in companies presented to the Workshop Humanizing the firm and the management profession,” IESE, June 30 - July 2.

Bénabou, R. and J. Tirole (2003), "Intrinsic and extrinsic motivation," Review of Economics Studies, 70, pp. 489-520.

Bolton, G. and A. Ockenfels (2000), "ERC - a theory of equity, reciprocity, and competition," American Economic Review, 90, pp. 166-193.

Casson, M. (2000), "An entrepreneurial theory of the firm," in N. J. Foss and V. Mahnke (eds.), "Competence, Governance and Entrepreneurship: Advances in Economic Strategy Research," (New York, NY: Oxford University Press), pp. 116-145.

Cheung, S. N .S. (1983), "The contractual nature of the firm," Journal of Law and Economics, 26, pp. 1-22.

Coase, R. H. (1937), “The nature of the firm,” Economica, NS, 4, pp. 386-405.

Cremer, J. (1990), "Common knowledge and the coordination of economic activities," in M. Aoki, O. E. Williamson, and B. Gustafsson (eds.), "The Firm as a Nexus of Treaties," (London, UK: Sage), pp. 53-76.

Cyert, R. M. and J. G. March (1963), “A Behavioral Theory of the Firm,” (Englewood Cliffs, N.J.: Prentice Hall).

Deci, E. L. (1975), “Intrinsic Motivation,” (New York, NY: Plenum Press).

Donaldson, L. (2002), "Damned by our own theories: Contradictions between theories and management education," Academy of Management Learning and Education, 1, pp. 96-106.

Dulbecco, P. and P. Garrouste (1999), "Towards an Austrian theory of the firm," Review of Austrian Economics, 12, pp. 43-64. 
Dulbecco, P. and P. Garrouste (2000), "Structure de la production et structure de la connaisance: éléments pour una theorie autrichienne de la firme,” Revue Économique, 51, pp. 75-101.

Fama, E. (1980), "Agency problems and the theory of the firm," Journal of Political Economy, 26, pp. 288-307.

Fehr, E. and K. Schmidt (1999), "A theory of fairness, competition and cooperation," Quarterly Journal of Economics, 114, pp. 817-868.

Ferraro, F., J. Pfeffer, and R. I. Sutton (2005), "Economics language and assumptions: How theories can become self-fulfilling," Academy of Management Review, 30, pp. 8-24.

Finnis, J. (1998), “Aquinas. Moral, Political, and Legal Theory,” (Oxford, UK: Oxford University Press).

Foss, N. J. (1994), "The theory of the firm: The Austrians as precursors and critics of contemporary theory," Review of Austrian Economics, 7, pp. 31-65.

Foss, N. J. (2007), “The knowledge governance approach,” Organization, 14, pp. 29-52.

Foss, N. J. and P. G. Klein (2005), "Entrepreneurship and the theory of the firm: Any gains from trade?," in R. Agarwal, S. A. Alvarez and 0. Sorenson (eds.), "Handbook of Entrepreneurship: Disciplinary Perspectives," (Berlin: Springer), pp. 55-80.

Foss, N. J. and P. G. Klein (2006), "The emergence of the modern theory of the firm," Center for Strategic Management and Globalization, Copenhagen Business School, Working Paper No. 1/2006.

Foss, N. J. and P. G. Klein (2008), "The theory of the firm and its critics: A stocktaking and assessment," in E. Brousseau and J. M. Glachant (eds.), "Handbook of New Institutional Economics," (Cambridge, UK: Cambridge University Press), pp. 425-442.

Foss, N. J. and P. G. Klein (2009), “Organizational governance," in R. Wittek, T. Snijders, and V. Nee (eds.), "Handbook of Rational Choice Theory," (New York, NY: Russell Sage Foundation).

Fransman, M. (1994), "Information, knowledge, vision and theories of the firm," Industrial and Corproate Change, 3, pp. 713-757.

Frey, B. S. (1997), "Not Just for the Money: An Economic Theory of Personal Motivation," (Aldershot, UK: Edward Elgar).

Frey, B. S. (1999), "Economics as a Science of Human Behaviour. Towards a New Social Science Paradigm,” 2nd ed., (Dordrecht: Kluwer).

Frey, B. S. (2003), "Corporate governance: What can we learn from public governance?," Working Paper, Institute for Empirical Economic Research, University of Zurich.

Frey, B. S. (2010), "Superb Posner - but can we go further?," Journal of Institutional Economics, 6, pp. 65-69.

Frey, B. S. and S. Meier (2002), "Pro-social behavior, reciprocity, or both?," CESIFO Working Paper No. 750, Munich.

Ghoshal, S. and P. Moran (1996), "Bad for practice: A critique of transaction cost theory," Academy of Management Review, 21, pp. 13-47.

Grandori, A. (2001), “Organization and Economics Behavior,” (London, UK: Routledge). 
Grossman, S. and 0. Hart (1986), 'The costs and benefits of ownership: A theory of vertical integration," Journal of Political Economy, 94, pp. 691-719.

Henderson, R. M. and K. B. Clark (1990), "Architectural innovation: The reconfiguration of existing product technologies and the failure of established firms," Administrative Science Quarterly, 35, pp. 9-30.

Holmström, B. and J. Tirole (1989), "The theory of the firm," in R. Schmalensee and R. D. Willig (eds.), "Handbook of Industrial Organization," Vol. I (Amsterdam: North Holland), pp. 61-133.

Ioannides, S. (1999), "Towards an Austrian perspective of the firm," Review of Austrian Economics, 11, pp. 77-97.

Ioannides, S. (2003), "Orders and organizations: Hayekian insights for a theory of economic organization," American Journal of Economics and Sociology, 62, pp. 533-566.

Jensen, M. C. and W. Meckling (1976), "The theory of the firm: Managerial behavior, agency costs and organizational structure,” Journal of Financial Economics, 3, pp. 305-360.

Kahneman, D. and A. Tversky (2000), “Choices, Values, and Frames," (Cambridge, UK: Cambridge University Press).

Khalil, E. (1998), “The Janus hypothesis," Journal of Post Keynesian Economics, 21, pp. 315-342.

Kirzner, I. M. (1973), “Competition and Entrepreneurship,” (Chicago, IL: University of Chicago Press).

Knight, F. H. (1921), [1965], “Risk, Uncertainty, and Profit,” (Boston, MA: Houghton Mifflin).

Kogut, B. and U. Zander (1992), "Knowledge of the firm, combinative capabilities, and the replication of technology," Organization Science, 3, pp. 383-397.

Kogut, B. and U. Zander (1996), "What firms do? Coordination, identity and learning," Organization Science, 7, pp. 502-518.

R. N. Langlois (1991), "Transaction cost economics in real time," Industrial and Corporate Change, 1, pp. 99-127.

Langlois, R. N. (1992), "Orders and organizations: Toward and Austrian theory of social institutions," in B. J. Caldwell and S. Boehm (eds.), "Austrian Economics: Tensions and New Directions,” (Boston, MA: Kluwer Academic Publishers), pp. 175-198.

Langlois, R. N. and N. J. Foss (2009), "Capabilities and governance: The rebirth of production in the theory of economic organization," Kyklos, 52, pp. 201-218.

Langlois, R. N. and P. L. Robertson (1995), "Firms, Markets and Economic Change: A Dynamic Theory of Business Institutions," (London, UK: Routledge).

Lewin, P. and S. E. Phelan (2000), "An Austrian theory of the firm," Review of Austrian Economics, 13, pp. 59-79.

Loasby, B. J. (2009), "Knowledge, coordination and the firm: Historical perspectives," European Journal of the History of Economic Thought, 16, pp. 539-558.

March, J. G. (1994), “A Primer on Decision Making: How Decisions Happen,” (New York, NY: Macmillan). 
March, J. G. and H. A. Simon (1958), “Organizations,” (New York, NY: John Wiley \& Sons).

Martínez-Echevarría, M. A. (2000), "Hacia una nueva teoría de la empresa," Cuadernos Empresa y Humanismo, Universidad de Navarra, No. 79,

Martínez-Echevarría, M. A. (2005), "Dirigir empresas: De la teoría a la realidad," (Madrid: Ediciones Internacionales Universitarias).

Nelson, R. R. and S G. Winter (1982), "An Evolutionary Theory of Economic Change," (Cambrige, MA: Harvard University Press).

Nonaka, I. and H. Takeuchi (1995), “The Knowledge-Creating Company," (New York, NY: Oxford University Press).

O'Driscoll, G. P. and M. J. Rizzo (1985), “The Economics of Time and Ignorance," (Oxford, UK: Basil Blackwell).

Osterloh, M. and B. S. Frey (1997), "Managing motivation: crowding effects in the theory of the firm,” Institut für betriebswirtschaftliche Forschung, Zürich, Working Paper No. 31.

Penrose, E. T. (1959), [1995], "The Theory of the Growth of the Firm," (Oxford, UK: Oxford University Press).

Pérez López, J. A. (1981), "Dimensiones de la responsabilidad social en la empresa," Research Paper, IESE, no. 49, January.

Pérez López, J. A. (1990), "I am the boss. Why should I be ethical?," in G. Enderle, B. Almond, and A. Argandoña (eds.), "People in Corporations. Ethical Responsibilities and Corporate Effectiveness," (Dordrecth: Kluwer).

Pérez López, J. A. (1991), "Teoría de la acción humana en las organizaciones. La acción personal," (Madrid: Rialp).

Pérez López, J. A. (1993), “Fundamentos de la dirección de empresas,” (Madrid: Rialp).

Pérez López, J. A. (1998), “Liderazgo y ética en la dirección de empresas,” (Bilbao: Deusto).

Posner, R. A. (2010), "From the new institutional economics to organization economics: with applications to corporate governance, government agencies, and legal institutions," Journal of Institutional Economics, 6, pp. 1-37.

Richardson, G. B. (1972), “The organisation of industry,” Economic Journal, 82, pp. 883-896.

Robbins, L. C. (1932), "An Essay On the Nature and Significance of Economic Science," (London, UK: Macmillan).

Rosanas, J. M. (2001), “Herbert Simon (1916/2001) y Juan Antonio Pérez López (1934-1996), "In Memoriam,"” Revista Empresa y Humanismo, 4, pp. 317-331.

Rosanas, J. M. (2008), "Beyond economic criteria: A humanistic approach to organizational survival," Journal of Business Ethics, 78, pp. 447-462.

Ross, S. (1973), "The economic theory of agency: The principal's problem," American Economic Review, 63, pp. 134-139. 
Schelling, T. (1978), "Egonomics or the art of self-management," American Economic Review, 68, pp. 290-294.

Schumpeter, J. A. (1934), "The Theory of Economic Development: An Inquiry into Profits, Capital, Credit, Interest, and the Business Cycle," (Cambridge, MA: Harvard University Press).

Simon, H. A. (1955), "A behavioral model of rational choice," Quarterly Journal of Economics, 69, pp. 99-118.

Simon, H. A. (1991), “Organizations and markets,” Journal of Economic Perspectives, 5, pp. 25-44.

Simon, H. A. (1996), “The Sciences of the Artificial," 3rd. edition 2001 (Cambridge, MA: The MIT Press).

Stark, 0. (1995), "Altruism and Beyond. An Economic Analysis of Transfers and Exchanges within Families and Groups,” (Cambridge, UK: Cambridge University Press).

Wernerfelt, B. (1984), “A resource-based view of the firm," Strategy Management Journal, 5, pp. 171-180.

Williamson, 0. E. (1971), "The vertical integration of production: Market failure considerations," American Economic Review, 61, pp. 112-123.

Williamson, O. E. (1975), "Markets and Hierarchies: Analysis and Antitrust Implications," (New York, NY: Free Press).

Williamson, O. E. (1985), “The Economic Institutions of Capitalism,” (New York, NY: The Free Press).

Yu, T. F. (1999), "Toward a praxeological theory of the firm," Review of Austrian Economics, 12, pp. 25-41. 